\title{
Enterobacter Cloacae Sepsis Outbreak in Neonatal Intensive Care Unit Due to Contaminated Total Parenteral Nutrition Solution
}

\author{
Yenidoğan Yoğun Bakım Ünitesinde Kontamine Total Parenteral \\ Beslenme Solüsyonlarına Bağıl Enterobacter Cloacae Sepsisi
}

\author{
Şükran Köse1, Esra Özer2, Zeynep Gülay3, Gülgün Akkoçlu1, Halide Tokgöz1, Neval Ağuş1, \\ Önder Ergönül4, Recep Öztürk5 \\ 1 Tepecik Training and Research Hospital, Clinic of Infectious Diseases, Izmir, Turkey \\ 2 Muğla Sıtkı Koçman University Faculty of Medicine, Department of Pediatrics, Muğla, Turkey \\ ${ }^{3}$ Dokuz Eylül University Faculty of Medicine, Department of Microbiology, Izmir, Turkey \\ ${ }^{4}$ Koç University Faculty of Medicine, Department of Infectious Diseases and Microbiology, Istanbul, Turkey \\ 5 Istanbul University Cerrahpaşa Faculty of Madicine, Department of Infectious Diseases, Istanbul, Turkey
}

\section{ABSTRACT}

Aim: Outbreaks have been reported in risky clinical settings such as intensive care units. The aim of this report is to address the clinical importance of the sepsis outbreak occurring in a neonatal intensive care unit.

Materials and Methods: $0 n$ the day of the outbreak 45 neonates were hospitalizd in our neonatal intensive care unit. All 13 high-risk neonates in the clinic developed signs and symptoms of septic shock after the initiation of parenteral nutrition solutions. Blood and parenteral nutrition solutions were cultured from all newborns. DNA analysis was also performed using gel electrophoresis to identify the source.

Results: Enterobacter cloacae was identified in the blood cultures of 5 patients and in 11 samples of the parenteral solutions. DNA analysis by pulsed-field gel electrophoresis revealed the same profile among the isolates of all Enterobacter cloaceae.

Conclusion: The data from this investigation allow for the conclusion that the parenteral nutrition solutions were the source of the outbreak by Enterobacter cloaceae in all 13 newborns. Although the contamination of parenteral nutrition solution may occur in several ways, we think that establishing an action plan in every neonatal intensive care unit for the systematic and strategic approach on managing the risk and crisis of a sepsis outbreak is of great importance.

Keywords: Enterobacter cloacae, newborn, sepsis, outbreak, parenteral nutrition solution
ÖZ

Amaç: Salgınlar yoğun bakım servisleri gibi riskli klinik birimlerde görülmektedir. Bu makalede bir yenidoğan yoğun bakım ünitesinde gerçekleşen sepsis salgınının klinik önemini irdelemek amaçlanmaktadır. Gereç ve Yöntemler: Salgın başlangııında servisimizde toplam 45 hasta yatmakta idi. Bunlar arasında yüksek riskli olan 13 hastada, uygulanan parenteral beslenme başladıktan sonra septik şok belirti ve bulguları ortaya çıktı. Tüm bebeklerin kanından ve total parenteral beslenme solüsyonlarından kültür alındı. Etken mikroorganizmayı saptamak için DNA jel elektroforezi de yapıldı. Bulgular: Total parenteral beslenme solusyonlarının 11 'inde ve beş hastanın kan kültüründe Enterobacter cloacae üredi. Pulsed-field jel elektroforez yöntemi ile yapılan DNA analizinde tüm Enterobacter cloacae izolatlarının aynı profilde olduğu gösterildi.

Sonuç: Tüm 13 olguda yaşanan sepsis salgınının etkeni olarak parenteral beslenme solüsyonlarını kontamine eden Enterobacter cloaceaénin varlığı gösterilmiştir. Parenteral beslenme solüsyonunda bulaşma çok farklı nedenlerle ortaya çıksa bile, tüm yenidoğan yoğun bakım servislerinde sepsis salgını ile ilişkili risk ve kriz yönetimine dair sistematik ve stratejik yaklaşım için aksiyon planı oluşturulmasının önemi vardır.

Anahtar Kelimeler: Enterobacter cloacae, salgın, sepsis, yenidoğan, yoğun bakım servisi, parenteral beslenme solüsyonu 


\section{Introduction}

Enterobacter cloaceae (E. cloacae), a saprophytic microorganism of the normal digestive flora in humans, is one of the most frequently isolated clinical species from septic patients' blood samples $(1,2)$. Outbreaks due to exogenous $E$. cloacae infection have been reported in various clinical settings including neonatal intensive care units (NICUs). E. cloacae can be responsible for urinary tract infection, bloodstream infection and pneumonia in hospitalized neonates (3-5).

An important source of infection is contaminated parenteral solutions (6-10). The contamination of parenteral nutrition solution may occur in several ways including the use of components contaminated during the manufacturing process, preparation, storage and administration of the solution (6,11-13).

The aim of this paper is to address the clinical features of a sepsis outbreak in an NICU resulting from the infusion of contaminated parenteral nutrition solution.

\section{Materials and Methods}

Tepecik Training and Research Hospital, Neonatology Clinic is a tertiary NICU and consists of 35 incubators, 15 baby cots and 16 for mechanical ventilation. Standard infection control measures are implemented in the care of all patients. Parenteral nutrition solutions are prepared in the parenteral nutrition clean room with the use of aseptic techniques under laminar flow by a single staff nurse and stored in the refrigerator on $+4{ }^{\circ} \mathrm{C}$.

On the day of the outbreak, 45 neonates were hospitalized in the clinic and 20 patients received total parenteral nutrition. Thirteen of those 20 high-risk neonates in the NICU developed signs and symptoms of septic shock after the initiation of parenteral nutrition solutions. No other patients had received this solution on that day. During an 18-hour period, 13 patients died despite prompt therapy with vancomycin and meropenem. Time of death were noted in the patients' records. Blood and parenteral nutrition solutions were cultured from all newborns. DNA analysis was also performed using gel electrophoresis to identify the source. This study was approved by Local Ethic Committee.

\section{Results}

The laboratory examination revealed thrombocytopenia and elevated C-reactive protein in the 13 septic newborns that died in the outbreak. Clinical data are shown in Table I. Four of the 13 newborns were female. Gestational age ranged from 26 to 33 weeks (median, 28 weeks), birth weight ranged from 860 to $1.450 \mathrm{~g}$ (median, $1.100 \mathrm{~g}$ ), and postnatal age ranged from 2 to 24 days (median, 9 days).

E. cloacae was identified in the blood cultures of 5 patients and in 11 samples of the parenteral solutions. The identification was positive in the amino acid and dextrose components of the solutions but not the lipid component. The isolates were sensitive to aztreonam, cefuroxime, ceftazidime, ceftriaxone, cefepime, piperacillin-tazobactam, amikacin, gentamicin, tobramycin, trimethroprim-sulfamethoxazole, ciprofloxacin, levofloxacin, imipenem, meropene but resistant to ampicillin, nitrofurantoin, ampicillin-sulbactam and cefazoline. DNA analysis by pulsed-field gel electrophoresis revealed the same profile for the isolates of all E. cloacae (Figure 1). Swabs taken from laminar flow hoods and from the surfaces of compounding equipment were negative for E. cloacae. The hand swabs from the staff during the outbreak and from

\begin{tabular}{|l|l|l|l|l|l|}
\hline \multicolumn{6}{|l}{$\begin{array}{l}\text { Table I. Characteristics of the } 13 \text { neonates with nosocomial sepsis } \\
\text { caused by Enterobacter cloacae }\end{array}$} \\
\hline Case & $\begin{array}{l}\text { Gestational } \\
\text { age (week) }\end{array}$ & $\begin{array}{l}\text { Birth } \\
\text { weight } \\
\mathbf{( g )}\end{array}$ & Gender & $\begin{array}{l}\text { Type of } \\
\text { delivery }\end{array}$ & $\begin{array}{l}\text { Postnatal } \\
\text { age (day) }\end{array}$ \\
\hline 1 & 27 & 1000 & M & Normal & 24 \\
\hline 2 & 27 & 1000 & F & Normal & 2 \\
\hline 3 & 26 & 860 & F & Normal & 4 \\
\hline 4 & 28 & 1100 & F & Normal & 17 \\
\hline 5 & 31 & 1450 & M & C/S & 9 \\
\hline 6 & 27 & 900 & F & C/S & 2 \\
\hline 7 & 26 & 970 & F & C/S & 16 \\
\hline 8 & 27 & 1190 & F & Normal & 7 \\
\hline 9 & 28 & 1050 & M & Normal & 2 \\
\hline 10 & 29 & 1200 & M & C/S & 16 \\
\hline 11 & 33 & 1200 & F & C/S & 10 \\
\hline 12 & 28 & 1150 & F & Normal & 10 \\
\hline 13 & 29 & 1220 & F & C/S & 6 \\
\hline C/S: Cesarean section, M: Male, F: Female & & \\
\hline & & & & \\
\hline
\end{tabular}

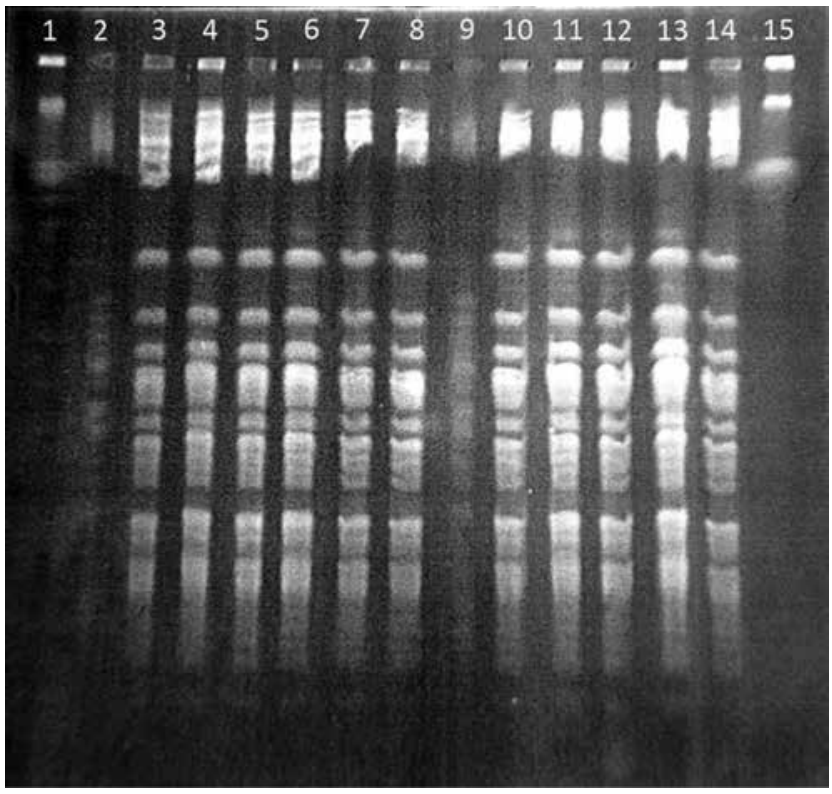

Figure 1. DNA analysis by pulsed-field gel electrophoresis of Enterobacter cloaceae 
Köse et al.

Total Parenteral Nutrition and Enterobacter Cloacea Sepsis

\begin{tabular}{|c|c|c|c|c|}
\hline Case & Antenatal problems & Diagnosis & Blood culture & TPN culture \\
\hline 1 & Perinatal asphyxia & RDS, pneumothorax & $\varnothing$ & E. cloacea \\
\hline 2 & None & RDS & E. cloacea & E. cloacea \\
\hline 3 & None & RDS & E. cloacea & E. cloacea \\
\hline 4 & P-PROM & RDS, sepsis & $\varnothing$ & E. cloacea \\
\hline 5 & Perinatal asphyxia & RDS, ICH & $\theta$ & $\theta$ \\
\hline 6 & P-PROM & RDS, sepsis & $\emptyset$ & E. cloacea \\
\hline 7 & Perinatal asphyxia & RDS, PDA & $\theta$ & E. cloacea \\
\hline 8 & None & RDS & $\varnothing$ & E. cloacea \\
\hline 9 & None & RDS & $\varnothing$ & $\varnothing$ \\
\hline 10 & Early neonatal death in previous sibling & RDS & E. cloacea & E. cloacea \\
\hline 11 & IUGR & NEC & E. cloacea & E. cloacea \\
\hline 12 & Perinatal asphyxia & RDS & E. cloacea & E. cloacea \\
\hline 13 & Chorioamnionitis & RDS & $\theta$ & E. cloacea \\
\hline
\end{tabular}

the nurse who prepared the parenteral nutrition solutions on the following day were also negative. Postmortem examinations confirmed the diagnosis of E. cloacae sepsis in all 13 patients. Table II shows that the patients were critically ill suffering from antenatal problems and complications of preterm birth and prematurity.

\section{Discussion}

Enterobacter species have been recognized as increasingly frequent causes of nosocomial infections (1416). Because a similar organism with the same pattern of antibiotic sensitivity was isolated, it is important to identify the source of contamination.

Some outbreaks caused by intrinsic contamination of the infusion solutions have been reported $(9,17)$. Such contamination may be detected in several hospitals at the same time when a common compound is used in the parenteral nutrition solutions resulting in an intrinsic contamination from the manufacturer. It is unlikely to conclude a similar contamination route in the present outbreak.

The contamination of parenteral nutrition solution may occur in several ways including the use of components contaminated during the manufacturing process, inadequate aseptic technique during the preparation of the solution, sterilization failures, contamination of the multidose lipid emulsion or dextrose solution, contamination of the solution during storage, technical problems during the administration of the solution or ascending method of infusions $(6,11-13)$.

An outbreak of clinical sepsis in a newborn nursery in Brazil was associated with contaminated parenteral medications. Resulting investigation concluded that the locally produced IV solutions were the source of the contamination (18). Similarly the source of the outbreak in our clinic was the parental nutritional solution contaminated by $E$. cloacae. The results of investigations strongly suggested that the nosocomial sepsis and the molecular typing method were helpful in clarifying the genomic evidence of the E. cloacae strains and confirming the common source of the contamination.

The parental nutrition solutions were prepared in a local setting, therefore contamination during transportation can be eliminated. We think that solutions were likely to be contaminated during preparation, because according to the electronic records of the preparation process, the parental nutrition had been administrated consecutively in these 13 patients after changing the vials of fluids. A hand swab from the staff nurse could not have been taken on site because her shift was over before the outbreak. Therefore the evidence of nosocomial contamination can not be confirmed.

\section{Conclusion}

Although the exact source of contamination could not be identified, we think that the source of the sepsis outbreak in our clinic is more likely to be the E. cloacae contaminated parental nutrition solution. The lesson taken from our experience is to establish an action plan in every $\mathrm{NICU}$ for the systematic and strategic approach on managing the risk and crisis of a sepsis outbreak.

\section{Ethics}

Ethics Committee Approval: It was taken, Informed Consent: It was taken.

Peer-review: External and Internal peer-reviewed.

\section{Authorship Contributions}

Concept: Şükran Köse, Design: Şükran Köse, Esra Özer, Data Collection or Processing: Gülgün Akkoçlu, Halide Tokgöz, Neval Ağuş, Analysis or Interpretation: Zeynep Gülay, Recep Öztürk, Önder Ergönül, Writing: Esra Özer.

Conflict of Interest: No conflict of interest was declared by the authors.

Financial Disclosure: The authors declared that this study received no financial support. 


\section{References}

1. Thomas A, Lalitha MK, Jesudason MV, John S. Transducer related Enterobacter cloaceae sepsis in post-operative cardiothoracic patients. J Hosp Infect 1993;25:211-4.

2. Wang CC, Chu ML, Ho LJ, Hwang RC. Analysis of plasmid pattern in paediatric intensive care unit outbreaks of nosocomial infection due to Enterobacter cloaceae. J Hosp Infect 1991;19:33-40.

3. Modi N, Damjanovic V, Cooke R. Outbreak of cephalosporin resistant Enterobacter cloacae infection in a neonatal intensive care unit. Arch Dis Child 1987;62:148-51.

4. Anderson LA, Hieber JP. An outbreak of gentamicin-resistant Enterobacter cloacae infections in pediatric intensive care unit. Infect Control 1983;4: 148-52.

5. Van den Berg RW, Claahsen HL, Niessen M, Muytjens $H L$, Liem K, Voss A. Enterobacter cloacae outbreak in the NICU related to disinfected thermometers. J Hosp Infect 2000;45:29-34.

6. Archibald LK, Ramos M, Arduino MJ, et al. Enterobacter cloacae and Pseudomonas aeruginosa polymicrobial bloodstream infections traced to extrinsic contamination of a dextrose multidose vial. J Pediatr 1998;133:640-4.

7. Fok TF, Lee CH, Wong EM, et al. Risk factors for Enterobacter septicemia in a neonatal unit: case-control study. Clin Infect Dis 1998;27:1204-9.

8. Freund HR, Rimon B. Sepsis during total parenteral nutrition. JPEN J Parenter Enteral Nutr 1990;14:39-41.

9. Matsaniotis NS, Syriopoulou VP, Theodoridou MC, Tzaneton $\mathrm{KG}$, Mostrou GI. Enterobacter sepsis in infants and children due to contaminated intravenous fluids. Infect Control $1984 ; 5: 471-7$.
10. Thompson $B$, Robinson LA. Infection control of parenteral nutrition solutions. Nutr Clin Pract 1991;6:49-54.

11. Llop JM, Mangues I, Perez JL, Lopez P, Tabau M. Staphylococcus saprophyticus sepsis related to total parenteral nutrition admixtures contamination. J Parenter Enteral Nutr 1993;17:575-7.

12. Tresoldi AT, Padoveze MC, Trabasso P, et al. Enterobacter cloacae sepsis outbreak in a newborn unit caused by contaminated total parenteral nutrition solution. Am J Infect Control 2000;28:258-61.

13. Dugleux G, Contour X, Hecquard C, Oblin I. Septicemia caused by contaminated parenteral nutrition pouches: the refrigerator as an unusual cause. J Parenter Enteral Nutr 1991;15:474-5.

14. Sanders WE Jr, Sanders CC. Enterobacter spp.: pathogens poised to flourish at the turn of the century. Clin Microbiol Rev 1997;10:220-41.

15. Stoesser N, Sheppard AE, Shakya M, et al. Dynamics of MDR Enterobacter cloacae outbreaks in a neonatal unit in Nepal: insights using wider sampling frames and next-generation sequencing. J Antimicrob Chemother 2015;70:1008-15.

16. Poirel L, Yilmaz M, Istanbullu $A$, et al. Spread of NDM-1producing Enterobacteriaceae in a neonatal intensive care unit in Istanbul, Turkey. Antimicrob Agents Chemother 2014;58:2929-33.

17. Maki DG, Rhame FS, Mackel DC, Bennett JV. Nationwide epidemic of septicemia caused by contaminated intravenous products. I. Epidemiologic and clinical features. Am J Med 1976;60:471-85.

18. Centers for Disease Control and Prevention (CDC). Clinical sepsis and death in a newborn nursery associated with contaminated parenteral medications-Brazil, 1996. MMWR Morb Mortal Wkly Rep 1998;47:610-2. 